\title{
Organic Pineapple Production Technology in Tripura - The lone AEZ for Fruits in North East India
}

\author{
Utpal Das $^{1 *}$, R.K. Bhattacharyya ${ }^{2}$, Debashish Sen $^{3}$, Panchaal Bhattacharjee ${ }^{4}$ and \\ Pramila Choudhury ${ }^{5}$
}

${ }^{1}$ VIT School of Agricultural Innovations and Advanced Learning (VAIAL), VIT, Vellore, Tamil Nadu, India

${ }^{2}$ Assam Agricultural University, Jorhat, Assam, India

${ }^{3}$ College of Agriculture, Tripura, India

${ }^{4}$ Anand Agricultural University, Anand, Gujarat, India

${ }^{5}$ Gandhi Institute of Engineering and Technology University, Gunupur, Odisha, India

*Corresponding author: utpaldashorts14@gmail.com (ORCID ID: 0000-0002-2618-0287)

Paper No. 891

Received: 20-04-2021

Revised: 24-05-2021

Accepted: 16-06-2021

\begin{abstract}
Tripura is a land of high hills, hillocks, interspersed with rivers and valleys having moderately warm and humid climate, well distributed annual rainfall of $2500 \mathrm{~mm}$. The terrain soil and climate of Tripura are ideally suited for rain-fed Horticulture. Tripura, being endowed with fertile soils, abundant moisture and sub-tropical climate offer immense scope for production of a wide variety of tropical and sub-tropical fruits. The climatic conditions of the state suitable for production of a large variety of horticultural crops chief among which include 'Queen' and 'Kew'; varieties of Pineapple. Pineapple (Ananas comosus L.) is a monoecious, monocotyledonous, monocarpic and xerophytic herbaceous perennial plant and its perennial in nature is propitiated through suckers. 'Queen' and 'Kew' ('Smooth Cayenne') are the main cultivars grown in different parts of Tripura. Among the states of north east India Assam is leading in terms of area and production and Tripura is just behind the Assam both in terms of area and production. Tripura produces 178.45 thousand MT from 12.57 thousand ha area (Anonymous, 2017), which is India's fifth leading state of in pineapple production and Tripura is also share 9.30 per cent of India's total pineapple production. The variety 'Queen' being the most popular for fresh consumption and occupying the largest area. These varieties are well known in the rest of the country. These Fruit products are free of any chemical residue thus making the fruits of Tripura products of organic farming. Pineapple production for export market is a realistic for organic cultivation for small scale organic farmers. The positive effects of organic pineapple production by default in Tripura competing on the global export market for pineapple.

\section{HIGHLIGHTS}

( Organic cultivation and competitiveness of pineapple products in the international market was decided to set up an Agri Export zone for Pineapple in Tripura

( Exporting of organic Pineapple will greatly increase the economic benefits of pineapple cultivation in Tripura.
\end{abstract}

Keywords: Pineapple, Organic Farming, Agri Export Zone (AEZ)

The hilly states in north eastern India are not only famous for their forest wealth and fascinating wild assets. These states are also known for their track record in harvesting specific crops and fruits. Some of the iconic ones are like, "Assam tea" which is famous in and outside India and popularity of "Khasi mandarin" is also well known. The small landlocked state Tripura produces quality

How to cite this article: Das, U., Bhattacharyya, R.K., Sen, D. Bhattacharjee, P. and Choudhury, P. 2021. Organic Pineapple Production Technology in Tripura - The lone AEZ for Fruits in North East India. IJAEB, 14(2): 149-158.

Source of Support: None; Conflict of Interest: None 
Pineapples in abundant amounts, where cv. Queen is popular among the growers. Sikkim and other states of north eastern region of India is known for their Organic Farming techniques, which is mostly attributed the nature of hill farming on this region. North-East is rich in horticultural aspect viz., floriculture with a rich variety of medicinal plants grown there along with various fruits and vegetables. An analysis of NSSO survey data on cultivation practices shows that the North-East hill states have retained traditional practices and show an inclination towards organic agriculture that is harnessed for the development of the region with ecological benefits. Use of chemical fertilizers in agriculture enhances yields but also undermines the quality of life through possible contamination of soil, water and air and even the final products that retain their residues. Such activities in hilly regions can have external effects on other regions as well.

The pineapple (Ananas comosus L.) is one of the leading commercial fruit crops of the tropics. Pineapple is also a commercially important fruit crop of India with around 105,000 ha area under this crop, 17.29 lakh tonnes annual production and 16.46 tonnes /ha productivity (Anonymous, 2017). Pineapple is one of the choicest fruit all over the world because of its pleasant taste and flavour. It is a good source of vitamin A and B and fairly rich in vitamin $C$ and minerals like calcium, magnesium, potassium and iron. It is also a source of bromelin, a digestive enzyme. In addition to being eaten fresh, the fruit can also be canned and processed in to different forms.

Tripura Queen Pineapple is characterized by its distinct aroma and pleasant organoleptic qualities with a comparatively lesser fibre content. Apart from this it is almost free from any chemical residue because of the attempt of organic cultivation practices followed by farmers at Tripura. The fruits are spiny, golden yellow in colour and release a pleasant aroma and flavour at the ripening stage. The fruits are harvested when eyes turns yellow during mid-May to mid-July when the fruit is available. Average weight of fruit varies from 1.0 to $1.5 \mathrm{Kg}^{\prime}$ s. It possesses all the good organoleptic qualities. Its juice is of bright yellow colour. A total Soluble solid (TSS) varies from 10 to $14^{\circ}$ Brix depending upon the stage of maturity and season and the $\mathrm{pH}$ value ranges from 4 to 4.5 . The water content is from $80 \%$ to $90 \%$. The "sweetness" and the "unique aroma' differentiates it with the Pineapples of other region of North East India.

Tripura Queen Pineapple is not found suitable for slices because of its smaller size and deep eyes. In order to increase the shelf life and to make pineapple juice and slices available even during off-season, canning is the most popular method. The waste parts left from canning plants, including the skin, core and ends, are used to make alcohol, vinegar and food for livestock.

\section{Nutritional Benefits}

Pineapples are nutritionally packed members of the Bromeliaceae family. This delightful tropical fruit is high in the enzyme Bromelain and the antioxidant vitamin $C$, both of which play a major role in the body's healing process. Bromelain is a natural antiinflammatory that has many health benefits and encourages healing. Pineapple fruit is very low in Saturated Fat, Cholesterol and Sodium.

- Tripura Queen Pineapples contains vitamin C, which is important for the immune and digestive systems

- Pineapples have anti-inflammatory effects which are good for those long hard days and those heroic sporting injuries

- They contain the enzyme Bromelain which is thought to aid digestion.

\section{Queen as the ideal Cultivar for Tripura}

It is the most popular and excellent cultivar of Tripura for fresh Consumption. The Queen Pineapple variety produced in Tripura is not just distinctly special in comparison with other varieties grown elsewhere in India but also significantly different in quality from the same variety grown in other adjacent states of North East. It is the most popular and excellent cultivar of Tripura for fresh consumption.

The plants are dwarf in stature and compact, habit of growth and bluish green foliage. The leaves are short stiff, spiny along the margins and thickly covered with a whitish bloom in both surfaces. The fruit weighs $0.8-1.3 \mathrm{~kg}$. Peduncle is short, fruit-lets or eyes are small, prominent, deep set. When fully mature, the fruits of Tripura Queen Pineapple are spiny, golden yellow in colour and emit pleasant 
aroma and flavour at the ripening stage. The flesh, although less juicy than Cayenne, is crisp (less fibrous), transparent with a pleasant aroma and flavour. The total soluble solids (TSS) content varies from 13 to $17.2{ }^{\circ}$ brix and acidity varied $0.6-0.8 \%$. The slips are 1 - 4, suckers 1 - 3 and both are smaller in size than those of Cayenne.
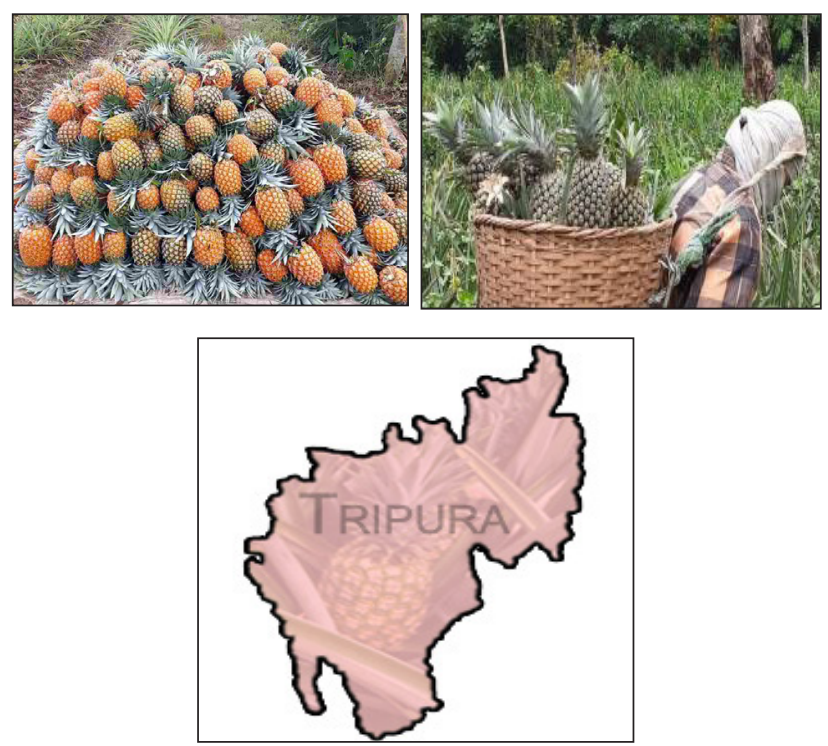

Although these fruits are smaller than the majority of other types of pineapple, but it charms consumers with their golden yellow pulp and delicious fragrance. The juice is bright yellow in colour and possesses very pleasant organoleptic qualities. The sweetness and unique aroma of Tripura Queen Pineapple differentiates it with Queen Pineapple of other region of North East India. The TSS (total soluble solids) (o Brix) content of Tripura queen pineapple is comparatively higher 13-18 ${ }^{\circ}$ Brix whereas Total sugar \% ranges from $13-14 \%$ depending upon the stage of maturity and season. One more feature that separates these pineapples from pineapples grown in other parts of the country is their lesser fiber content.

Quality parameters of queen pineapple in NER as per ICAR research complex for NEH region

\begin{tabular}{|c|c|c|c|c|c|c|}
\hline State & Variety & $\begin{array}{l}\text { Wt. of } \\
\text { fruit } \\
\text { (kg) }\end{array}$ & $\begin{array}{l}\text { TSS } \\
\left({ }^{\circ} \text { Brix }\right)\end{array}$ & $\begin{array}{l}\text { Acidity } \\
(\%)\end{array}$ & $\begin{array}{l}\text { Total } \\
\text { sugar } \\
(\%)\end{array}$ & $\begin{array}{l}\text { Vit-C } \\
\text { (mg/ } \\
100 \mathrm{~g})\end{array}$ \\
\hline Manipur & Queen & $0.6-1.0$ & $18-20$ & $0.5-0.6$ & - & - \\
\hline Meghalaya & Queen & $1.0-1.5$ & $18-20$ & $0.4-0.5$ & $14-16$ & - \\
\hline Nagaland & Queen & $1.2-1.5$ & $18-22$ & $0.3-0.4$ & $14-16$ & $50-54$ \\
\hline Tripura & Queen & $0.8-1.3$ & $13-17.2$ & $0.6-0.8$ & 13-14 & $28-30$ \\
\hline
\end{tabular}

\section{Suitable agro-climate}

One of the reasons for this success is the agro climatic conditions of Tripura, which are highly, conducive for cultivation of various horticulture crops and primarily 'queen', 'Kew,' varieties of Pineapple.

\begin{tabular}{|l|l|l|}
\hline $\begin{array}{l}\text { S1. } \\
\text { No. }\end{array}$ & $\begin{array}{l}\text { Ideal requirement for } \\
\text { pineapple cultivation }\end{array}$ & $\begin{array}{l}\text { Climatic condition of } \\
\text { Tripura }\end{array}$ \\
\hline 1 & $\begin{array}{l}\text { Slightly acidic soil } \\
\text { with pH range of } 5.5 \\
\text { to } 6.0 \text { is considered } \\
\text { optimum for } \\
\text { pineapple cultivation }\end{array}$ & $\begin{array}{l}\text { The pH values of Tripura } \\
\text { soils vary from } 4.05 \text { to } \\
6.05 \text { and in more than } \\
90 \text { percent of soils, pH is } \\
\text { bellow 5.6. }\end{array}$ \\
\hline 2 & $\begin{array}{l}\text { The fruits grows } \\
\text { well as long as } \\
\text { temperature ranges } \\
\text { from } 15.5 \text { to } 32.5^{\circ} \mathrm{C}\end{array}$ & $\begin{array}{l}\text { The maximum and } \\
\text { minimum temperature } \\
\text { during winter are } 27^{\circ} \mathrm{C} \\
\text { and } 13^{\circ} \mathrm{C} \text { and during } \\
\text { summer are } 35^{\circ} \mathrm{C} \text { and } 24^{\circ} \mathrm{C} \\
\text { respectively }\end{array}$ \\
\hline 3 & $\begin{array}{l}\text { Optimum rainfall } \\
\text { required for } \\
\text { pineapple is } 1500 \mathrm{~mm} \\
\text { per year all through }\end{array}$ & $\begin{array}{l}\text { The amount of average } \\
\text { total annual rainfall in the } \\
\text { state is } 2169.4 \mathrm{~mm} .\end{array}$ \\
\hline 4 & $\begin{array}{l}\text { Pineapple grows in } \\
\text { almost any type of } \\
\text { soil, provided it is } \\
\text { free-draining }\end{array}$ & $\begin{array}{l}\text { The fertile soil of Tripura } \\
\text { and well drained } \\
\text { topography of } \text { tilla } \text { (small } \\
\text { hillocks) land with } \\
\text { moderate steep slopes, } \\
\text { gentle to moderate slope } \\
\text { and rolling topography } \\
\text { provide the perfect } \\
\text { cultivation condition. }\end{array}$ \\
\hline
\end{tabular}

Owning to this high climatic suitability the farmers need not to use chemical inputs for cultivation and neither is there any requirement for irrigation. The North-East region produces more than $40 \%$ of the total pineapple of the country and almost 90 to $95 \%$ of the produce is organic. The common varieties produced from this region (North East) are qualitatively different and is said to be among the "Best in the world as they are very sweet (high TSS) with less fibre, The Tripura queen Pineapple produced in Tripura is free of any chemical residue thus making the fruits of Tripura by default Organic. The pineapple fruit are highly sensitive to direct sunlight. Both bright sunshine and total shade are harmful for the plant and deteriorates the quality of fruits and therefore shade management plays an important role in cultivation. Farmers at Tripura grow the Queen pineapple under the natural shaded canopy of various trees which primarily includes 


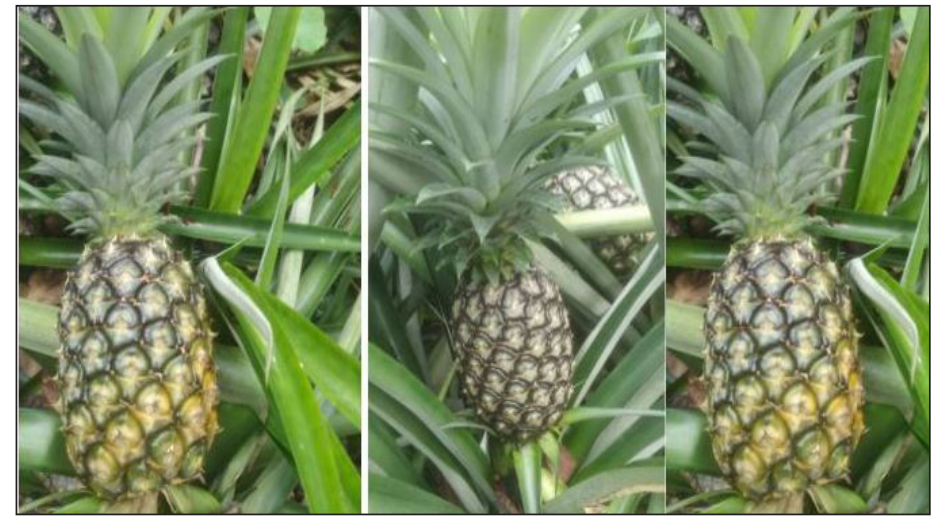

Kew

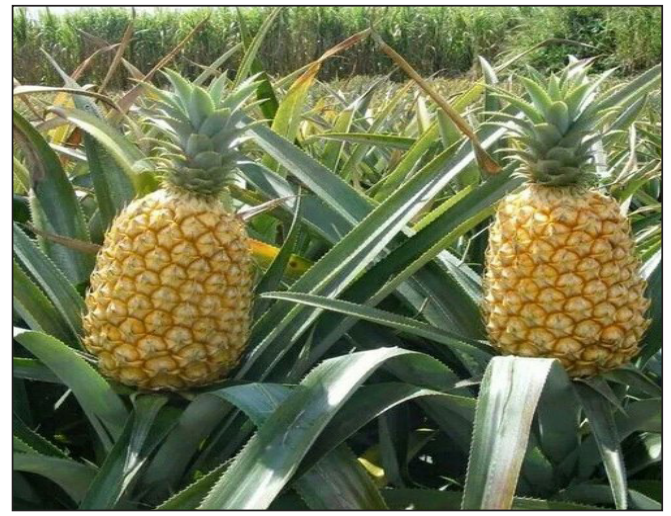

Queen
Jackfruit, Litchi and other trees. It is believed that Tripura Pineapple plants grown under the shade of jackfruits produces better quality of fruits.

\section{Package of practices for Organic Pineapple}

\section{Climate and Soil}

Pineapple is natural habitat of humid tropical region. Pineapple is an evergreen perennial plat which does not have dormancy and will continue to grow as long as environment favours. Most of the Pineapples are grown in the region between $25^{\circ} \mathrm{N}$ and south of equator.

Temperature range of $" 18^{\circ} \mathrm{C}$ to $32^{\circ} \mathrm{C}$ " is most favourable for Pineapple Cultivation. In Tripura the summers are warm to hot $\left(19^{\circ} \mathrm{C}\right.$ to $\left.36.8^{\circ} \mathrm{C}\right)$ and wet, while the winters are $\operatorname{cool}\left(8^{\circ} \mathrm{C}\right.$ to $\left.27.5^{\circ} \mathrm{C}\right)$ and comparatively dry. Plant growth decreases rapidly at mean temperatures below $15^{\circ} \mathrm{C}$ or above $32^{\circ} \mathrm{C}$. In Tripura low temperatures occur from December to January and potentially inhibit growth during winter and Queen Cultivar can initiate reproductive development below $10^{\circ} \mathrm{C}$; however fruit formation is drastically affected and will eventually impact on the harvest dates. High (above $35^{\circ} \mathrm{C}$ ) and low (below $10^{\circ} \mathrm{C}$ ) temperatures affect development and retard growth. Pineapple plants are most productive under dry environments where low rainfall is supplemented with irrigation in well drained soils. Pineapple performs well in relatively low water regimes; it requires as much as $5 \mathrm{~cm}$ of water per month from rain and irrigation, in the subtropical areas of Tripura elevation and aspects are of particular importance in deciding the site for pineapple cultivation. Therefore most pineapple plants are planted on hill sides of escape frost. Pineapple thrives well when planted on a north easterly aspect where they receive the maximum amount of sunlight.

\section{Soil}

Pineapple plants require sandy soil and good drainage to prevent water logging therefore purposely built raised beds on slopes are utilized. Well drained loamy soil with high organic matter and a $\mathrm{pH}$ of 4.5 - 6.5 with low Calcium content is best for pineapple Cultivation. The dark brown and reddish -brown basaltic and sandy loams are considered ideal for Pineapple production. The experiences of north eastern regions shows that fruit grows well in a wide range of soils, from the new alluvium of plains to old alluvium of the submountainous tracts as well as the lateritic soils of the hills so long as land is not waterlogged at any time of year. Probably no other fruit crop is possible where most of the Pineapple orchard are exists in the region

\section{Propagation}

Tripura Queen Pineapple is commercially propagated by suckers in Tripura. The suckers arise and grow from buds below the ground level. The slips arise from fruit stalks. They are smaller than suckers but borne more in number per plant than suckers. The crown grows on the top of the fruit. It is the vegetative growth at the top of the fruit, attached to the central core of the fruit. Fruit stalks cut into bits known as discs can also be used for propagation. Among sucker slips and crown the first two are better for early fruiting but for planting 
uniformity in sizes i.e. in terms of weight is a per condition for a uniform field and crop situation.

\section{Land preparation}

An area with $30-40 \%$ slope is generally selected for Tripura Queen Pineapple cultivation. In the North East Region, the most common method of initial clearing of the land for plantations is by way of slash-and-burn. No formal organic compost is added to the soil for planting. Only in cases where cow dung or other compost materials are available, they may be added to the pits that have been dug for plantation. The land is generally prepared by hoeing but in areas where the slope is not too steep, the land may be levelled by ploughing to facilitate uniform distribution of water and nutrients. Alternate crisscross rows are made using a bamboo across the slope, which helps in soil and water conservation. In most hill areas of the North East Region, the fields are not ploughed but uniform rows are demarcated either across the slopes or along the slopes where the suckers are planted at uniform spacing (in the case of mono-cultivation) or random spacing if planted along with other perennial crops such as banana, papaya, etc.

\section{Planting system}

The land should be thoroughly ploughed and pulverized to a good tilt. Tripura queen pineapple is mainly planted just at the onset or the offset of monsoon, in order to avoid heavy precipitation in the pre establishment period of the plants. Though the best time for plantation in Tripura would be May to June, but availability of suckers during this period is scarce as the fruits attaining maturity at this time and the cultivators are reluctant to for desuckering. So in general practice planting in Tripura is done during late August to early October taking the advantage of post monsoon soil moisture.

Before planting the suckers or slips should be sun cured and fry leaf scales at the base should be removed. Suckers should be planted in $10 \mathrm{~cm}$ deep hole but the heart of the suckers must not be buried. Planting may be done in single row or double rows following triangular and rectangular system. The following is the spacing required for different plant population per hectare.

\begin{tabular}{lllll}
\hline $\begin{array}{l}\text { Plant } \\
\text { population to plant within } \\
\text { per hectare a row }(\mathbf{c m})\end{array}$ & $\begin{array}{l}\text { Distance plant } \\
\text { row to row } \\
(\mathbf{c m})\end{array}$ & $\begin{array}{l}\text { Distance } \\
\text { trench to } \\
\text { trench } \\
(\mathbf{c m})\end{array}$ & $\begin{array}{l}\text { Yield } \\
(\mathbf{t} / \mathbf{h a})\end{array}$ \\
\hline 43,500 & 30 & 60 & 90 & 45.2 \\
53,300 & 25 & 60 & 90 & 51.6 \\
63,700 & 22.5 & 60 or 45 & 75 or 90 & 61.0 \\
\hline
\end{tabular}

Source: Singh 2005, a technology bulletin for Tripura, ICAR Study.

\section{Organic Cultivation}

The region has remarkable advantages of fertile and organically rich soils, ample rainfall and water resources, river valleys, swamps and streams and great climatic diversity supporting diverse cropping possibilities. Cultivation is based on organic manure and is accompanied to a significant extent with use of improved seeds. It is interesting to note that wastes via manure and the waste generation process through animal feed and vegetable waste are used North East region is so into organic farming that one would not come across a single fertilizer shop there. Thus, the Pineapple coming from this region is free of any chemical residue. In organic farming, no chemical fertilizers or pesticides are used. Normally farmers use urea to increase the weight of the pineapple, which is not used in organic farming. Because the crops cannot be treated (dipping) with insecticides/ fungicides on organic pineapple plantations, the farmer is forced to pay particular attention to the quality and origin of the shoots (diseases that can be transmitted from crop to crop). This is especially the case for shoots that have been bought. In principle, it is recommended to use shoots from the plantation itself and to work very carefully.

In the majority of organic plantations, local varieties are planted together with other crops either in agro forestry or mixed crop systems. Examples exist where Pineapples are planted as a rotationfruit with green fallow land and other crops. The farming plan will depend upon which cultivation form is adopted (agro forestry system, mixed crops as a bottom culture, crop-rotation etc.). A pineapple monoculture is not permitted in organic farming systems. To prepare the land used for pineapple production green manuring plants like e.g. Vigna unguiculata, Crotolaria juncea or Mucuna capitata can be sowed prior to the pineapples. 


\section{Interculture}

Earthling up is an essential operation in pineapple cultivation aimed at good anchorage to plants. It involves pushing the soil into the trench from the ridge where trench planting is a common practice. As the pineapple roots are very shallow, the plants are eventually lodged especially under conditions of flat-bed planting in heavy rainfall areas. Lodging of plants when the fruits are developing would result in lopsided growth, uneven development and ripening of fruits. This operation becomes more important in ratoon crops, as the base of the plant shifts-up, crop after crop. High-density planting would minimize the necessity of this operation, as the plants prop each other preventing lodging.

\section{Water management}

Tripura Queen Pineapple is grown mostly as a rain-fed crop in Tripura because the region receives ample rainfall. However, irrigation is necessary during dry spell, especially November to March at 20- 25 days interval ensure good crop. Off season production is not possible without 4-6 irrigations in dry hot months, since stomata of pineapple leaves never open during sunlight due to xerophytic nature of plants. The roots are very sensitive to water logging therefore, tilla (small hillocks) land is most suitable due to good drainage.

Tripura is one of the leading Pineapples growing State in the country. There are two varieties of pineapples available in the State, Kew variety which is the processing variety and the Queen variety, the table variety normally used for fresh consumption. The Pineapple season in Tripura ranges from the month of June to December with July-August as the peak months.

\section{Flower regulation using growth regulators}

Normally, pineapple flowers 10-12 months after planting and fruits are ready for harvest after 5-6 months of flowering. Besides time of planting, flower induction practices with certain chemicals or growth regulators influence the season of harvest. 25 ppm ethephon to mature plants with 39-42 leaves after 7-8 planting or Ethrel @ 0.025 ml/1 with 501 cow dung solution can be applied at centre portion. Ethrel@0.025 ml/1 + 2 \% urea + 0.04 \% Sodium carbonate induce more than $90 \%$ flowering, as urea helps in better absorption and sodium carbonate increases release of ethylene. Therefore for 1000 plants, 50 litres of solution has to be prepared by dissolving $1.25 \mathrm{ml}$ of ethrel $+1 \mathrm{~kg}$ of urea $+20 \mathrm{~g}$ of sodium carbonate. Around $50 \mathrm{ml}$ of this solution has to be poured in the crown. Similarly, 95 per cent of flowering within 56 days could be induced by applying $50 \mathrm{ml}$ of solution containing calcium carbide $(1 \%)$ and urea (2\%) at the age of 12 months. In ratoon crop of Giant Kew, calcium carbide (1\%) and urea $(2 \%)$ applied in the whorl of plants in September-October induced flowering within one month and the fruits were ready for harvesting in first week of March to end of May. The planting and flower induction schedule can be planned as follows so as to accomplish staggered harvest and unbroken market availability throughout the season i.e. from October to May. Although, growth regulators or chemicals can induce flowering at any stage of the plant growth, forcing the plants to produce flowers at an early stage reduces fruit size. Therefore, when plants of optimum size (35- 40 fully grown and active leaves) are induced to flower, better fruit size is obtained without any adverse effects on the ratoon crop.

\begin{tabular}{|c|c|c|c|}
\hline $\begin{array}{l}\text { Month of } \\
\text { Planting (I } \\
\text { year) }\end{array}$ & $\begin{array}{l}\text { Month of } \\
\text { application of } \\
\text { growth regulators } \\
\text { in the II year }\end{array}$ & $\begin{array}{l}\text { Months } \\
\text { taken for } \\
\text { flower } \\
\text { induction }\end{array}$ & $\begin{array}{l}\text { Harvesting } \\
\text { month }\end{array}$ \\
\hline April & March-April & $1-2$ & $\begin{array}{l}\text { October- } \\
\text { November }\end{array}$ \\
\hline May & April-May & $1-2$ & $\begin{array}{l}\text { November- } \\
\text { December }\end{array}$ \\
\hline August & July-August & $1-2$ & $\begin{array}{l}\text { February- } \\
\text { March }\end{array}$ \\
\hline September & August-September & $1-2$ & March-April \\
\hline October & September-October & $1-2$ & April-May \\
\hline November & October-November & $1-2$ & May-June \\
\hline
\end{tabular}

\section{Harvesting and Handling of Pineapple}

The period between planting and harvesting of pineapple is usually two to two and half years. The stage of maturity at harvest is dependent on the required storage or shelf-life and the method of transportation to the export markets. The level of yellow coloration of the "eyes" of the fruit judges maturity. Various colour stages are categorized as follows:

I. CS1: all eyes green, no traces of yellow; 
II. CS2: 5 to $20 \%$ of the eyes yellow;

III. CS3: 20 to $40 \%$ of the eyes yellow;

IV. CS4: 40 to $80 \%$ of the eyes yellow;

V. CS5: $90 \%$ of eyes yellow, 5 to $20 \%$ reddish brown;

VI. CS6: 20 to $100 \%$ of eyes reddish brown

Fruits are mainly harvested during July-August. However, a small crop is harvested during December to March also. By regulating the crop, harvesting is possible almost 8 month a year. Sugar content should be assessed in the field prior to harvesting to ensure adequate sugar development. A minimum of $10 \%$ is generally required although this may vary with the market. Sugar content is not always related to the colour stage as agronomic and production factors will affect sugar development. For the export market where sea-shipment for seven to fourteen days is used, fruits should be harvested at CS1, where the fruits show no yellow colour development on the eyes (ensuring that checks have been made on the sugar content). For air-freighted shipments, although generally cost prohibitive, harvesting can be carried out at CS2 to 3. Those harvested at more advanced stages are more susceptible to mechanical damage and over-ripeness. Fruit maturity can also be assessed on random samples by determination of the flesh condition. This is carried out by slicing the fruit horizontally at the point of largest diameter; in fruit for sea-shipment export; the fruit should show limited development of translucent areas. Where more than half of the area is translucent, the fruit is considered beyond optimum maturity. Pineapples harvested by hand are snapped from the stalk using a downward motion. The fruit should be placed in field crates and while in the field, left in shaded conditions. Collection in the field and field to pack house transport using sacks or bags will cause mechanical damage and increase the level of rejection. On arrival at the packing facility, the stems and the crowns should be trimmed to 2 $\mathrm{cm}\left(0.5^{\prime \prime}\right)$ and $10 \mathrm{~cm}\left(4^{\prime \prime}\right)$ respectively. Out grading should be made of all fruits which are undersize, oversize, over-ripe, under-ripe (depending on the market requirements), damaged, bruised or show fungal or insect damage.

\section{Yield}

According to records of the Agriculture department, Tripura's pineapples production estimated to be around 1, 26,994 tonnes during 2017-18. The area under cultivation is estimated every year across 8,728 hectare orchards in different districts including Sonamura in Sepahijala district, Kamalpur in North Tripura and Ambassa in Dhalai district, while the productivity is around $14.55 \mathrm{MT} / \mathrm{ha}$. While some of the orchards are run by the government, most of them are privately-owned. Over 4,000 pineapple growers are directly connected to the cultivation of the fruit. Two cultivars of pineapples are largely grown in the State, Kew variety which is the processing variety and the Queen variety, the table variety normally used for fresh consumption. The Pineapple season in Tripura ranges from the month of June to December with July to August as the peak months. Economic life of a pineapple plantation is expected to be around 4 years considering one main crop followed by two ratoons as the one crop cycle. On completion of one crop cycle the plantation is uprooted and the land is cleared and prepared for replanting adopting various soil fertility as well as soil amendment practices.

\section{Marketing and export}

There is always a very good demand of Indian pineapples in the internal markets. It is in high demand from the processing industry as well. Indian pineapple is exported to Nepal, U.K., Spain,

District wise Area \& Production of Pineapple during the year 2017-18 (Area in Ha, Production in MT \& Productivity in MT/Ha)

\begin{tabular}{llllllllll}
\hline \multirow{2}{*}{ Pineapple } & $\begin{array}{l}\text { South } \\
\text { District }\end{array}$ & $\begin{array}{l}\text { Gomati } \\
\text { District }\end{array}$ & $\begin{array}{l}\text { Sepahijala } \\
\text { District }\end{array}$ & $\begin{array}{l}\text { West } \\
\text { District }\end{array}$ & $\begin{array}{l}\text { Khowai } \\
\text { District }\end{array}$ & $\begin{array}{l}\text { Dhalai } \\
\text { District }\end{array}$ & $\begin{array}{l}\text { Unakoti } \\
\text { District }\end{array}$ & $\begin{array}{l}\text { North } \\
\text { District }\end{array}$ & $\begin{array}{l}\text { State } \\
\text { Total }\end{array}$ \\
\hline Area & 935 & 895 & 750 & 750 & 610 & 2503 & 884 & 1401 & 8728 \\
Production & 13093 & 12883 & 10995 & 10973 & 8857 & 36324 & 12783 & 21087 & $1,26,994$ \\
Productivity & & & & & & & & & 14.55 \\
\hline
\end{tabular}

Source: Directorate of Horticulture \& Soil Conservation, 2019. 
Italy and U.A.E. The main products of export are canned slices, titbits, juice etc. Now, Tripura to export queen pineapples with unique tags, logo. National Institute of Design has designed unique tags and logo for boxes to make the produce more attractive, while maintaining the quality of queen pineapples.

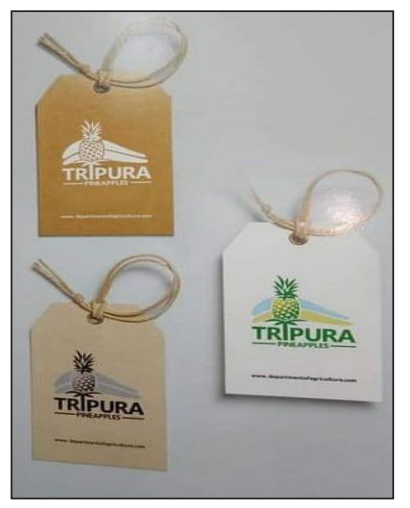

Corrugated fiberboard box

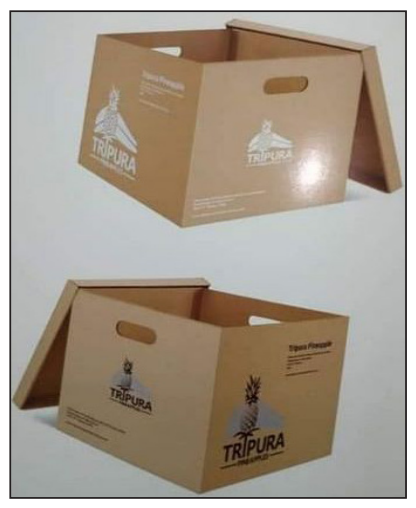

Tags

\section{Pineapple based industry in Tripura}

Tripura is one of the largest pineapple growing states in the country and there are more than 100 commercial scale pineapple plantations spread throughout the state. Tripura is turning into a commercial hub with large market in Japan, European countries and even in United States. Experiments on high density planting, staggered planting and use of flower inducing hormones are being conducted to increase the productivity of pineapples at the Horticultural Research Centre at Nagicherra, in West Tripura district. Preliminary results indicate the possibility of advancing the availability of pineapples by about two months before the normal season. Pineapple growers in the state have benefited from these results in terms of yield and increased availability period of fruit during the year. It has also helped in engaging the workers throughout the year, thus creating employment opportunity. This method was first introduced only in 25 ha of farm land in the year 2005 but it has now extended to 200 ha area.

Tripura State Horticulture Corporation is gearing up to sign a MoU with Dabur h/t. Ltd., Dharmapal Satpal Group of Industries and North Eastern Regional Marketing Company (NERAMAC) to sell raw pineapple to the tune of 71, $000 \mathrm{t} /$ year. NERAMAC had set up a fruit juice concentration plant, in the year 1988, in Nalkata with an initial capital investment of Rs.30 Million. The Tripura Small Scale Industries (TSSI) and NERAMAC are utilizing Tripura pineapples for making juice, jelly and concentrates. The biggest fruit processing units in Bangladesh, PRAN also utilizes pineapples of Tripura for making vermin products. For the last few years NEMMAC- the Central Agricultural Marketing Agency and Tripura Small Industries Corporation have come forward to help the grower by establishing mini-fruit processing units. But the capacity of these units is inadequate. Meanwhile, a Primary Agricultural Credit Society (PACS) has been set up to look after the marketing aspect of pineapples grown in Durchawi. Last year, the PACS arranged for the export of 1,200 million pineapples to Bangladesh.

Pineapple growers in Tripura are gearing up to meet the ltalian demand for canned and bottled pineapple products. The arrival of Pijush Agro Tech, a fruit processing unit in Ushabazar area in Agartala, provides the growers of pineapple with a new ray of hope.

Recently a tribal women group from Tripura's pineapple growing tracts is to put to use the technical back-up and training received from the South India Textile Research Association (SITRA) for commercial exploitation of pineapple leaf fibre (PALF).

\section{AEZ of pineapple}

The president of India Ram Nath Kovind decleared Tripura's Queen variety of pineapple as state fruit and said its export was a major step in connecting the state in world trade (The Times of India, 2018). The Ministry of Commerce and Industry has recently sanctioned the Agri Export Zone Scheme for the entire North East Region at Tripura. Under this scheme, enhanced international market access would be provided to the farmers besides necessary infrastructure, flow of credit transport assistance and other facilities for promoting agricultural export through pineapple cultivation. Apart from that the new export-import Policy of the Government has given a major thrust to agricultural export by removing export restrictions like registration requirement, minimum export price and exports through the State agencies. All these initiatives are expected to boost the trade potential of pineapples grown in Tripura and other parts of the region. 
In view of Tripura's inherent strength with regard to organic cultivation of this crop and also in view of the price competitiveness of pineapple products in the international market it was decided to set up an Agri Export zone for Pineapple. The zone will cover districts of Kumarghat, Manu, Melaghar, Matabari and Kakraban Blocks. This project involves a total investment of around Rs. 16 crores, out of which ₹ 8.11 crores will flow from the Central Government agencies, ₹ 1,16 crores from State Government agencies and the remaining by the private sector.

The following list shows the leading catchment areas of markets of Pineapple in Tripura in the three major districts.

\begin{tabular}{ll}
\hline District & Principle catchment Areas \\
\hline North Tripura & $\begin{array}{l}\text { Dharmanagar, Fatikrai, Kumarghat, } \\
\text { Vanghmuri, Phuldurgsai, Sakhan }\end{array}$ \\
Dhalai Tripura & $\begin{array}{l}\text { Kamalpur, Halhari, Salema, Kanchanpur, } \\
\text { Bahudurpura, Sakhn, Rabiraipara }\end{array}$ \\
West Tripura & $\begin{array}{l}\text { Khowal, Sidhai, Kalyanpur, Ranibazaar, } \\
\text { Jambal, Bisalgarh, Barjula, Sonamura, }\end{array}$ \\
& Kathalia, Teliamura \\
Unakoti & Darchoi, Jamtailbari, Deocherra \\
\hline
\end{tabular}

\section{Future prospect}

Naturally, many of the pineapple gardens were replaced with rubber plantations. The ones which couldn't be replaced still produced plenty to surpass the demand of the state, which reduced the prices (Market price of pineapple is ₹ $43 / \mathrm{kg}$ while retail price is ₹ $49-55 / \mathrm{kg}$ ) (Suchiradipta and Sarvanan 2018). In spite of that, with the current prices of pineapple in the state, the unit cost of investment is ₹ 40,936 per 0.4 acre ( 1 kani), which is affordable for a small farmer. The net income per unit is around ₹ 64,664 with $147 \%$ return on investment. Considering producers only get $30-40$ per cent of the consumer's money, better connectivity with consumers and reducing market intermediaries will greatly increase the economic benefits of pineapple cultivation in Tripura (MART, 2011). Lack of processing facilities or export initiatives resulted in wastage of huge quantity of pineapples in the state every year. With fall in rubber prices in the international markets, there has been a new found interest in pineapple production, processing, and export in the state. Presently, 8,848 ha area is under pineapple production with 128,971 tonnes yield (14.43 tonnes/ ha is the average productivity).
But so far, inadequate processing facilities in the state, so, rise in production without proper market or cold storage infrastructure will result in distress sale of the surplus (currently the wastage is up to $30 \%$ ), resulting in a more significant dip in interest of the growers to take up pineapple production. In the recent times, climate change is also adding to the woes of the pineapple farmers (Business Standard, 2016). Tripura has been notified as an Agri Export Zone (AEZ) for pineapple but except recent exports of few consignments to Dubai, the export to Bangladesh is also at standstill aggravating the market glut.

Pineapple exports to Bangladesh have been stopped for past few years which have hit the pineapple growers. Agricultural and Processed Food Products Export Development Authority (APEDA) has exported two consignments (1.05 tonnes each) of Kew variety of pineapple to Dubai in 2017 and based on the positive feedback and high demand, agreements for more are also underway (The Assam Tribune, 2018).

\section{REFERENCES}

Abu Osman, N, A., F. Ibrahim, W.A.B. Wan Abas, H.S. Abd Rahman, H.N. Ting. 2008. Bio-ethanol production from agricultural waste biomass as a renewable bio-energy resource in biomaterials. Biomed 2008, Proceedings 21, pp. 300-305.

Anonymous, 2013. Agricultural Marketing. Statistical Abstracts. National Institute of Agricultural Marketing. Jaipur, pp. 242-243.

Anonymus, 2017. Horticulture Statistics Division Department of Agriculture, Cooperation \& Farmers Welfare Ministry of Agriculture \& Farmers Welfare Government of India.

Bhattacharya, R.K. and Bhattacharyya, A.P. 1992. Crop production and harvest index of Kew pineapple as affected by foliar application of micronutrients. Acta Horticulturae (ISHS), 296: 161-164.

Business Standard, 2016. Pineapple growers are in 'double trouble' in Tripura. http://www.business-standard.com/ article/news-ani/pineapple-growers-in-double-troublein-tripura-116070900506_1. html (Updated on July 9, 2016; Accessed on May 22, 2020).

Chadha, K.L. 2001. Pineapple. The hand book of Horticulture. Directorate of information and publication of Agriculture. ICAR, New Delhi.

Chadha, K.L. Shikhamany, S.D. and Melanta, K.R. 1977. Ratoon cropping in high density pineapple plantations. Indian Horticulture, 22: 3-4.

Chandra Das, S., Prakash, J., Suresh, C.P., Das, A. and Bhattacharjee, T. 2011. Pineapple cultivation in hilly 
tripura with year around production: improving livelihood opportunities in rural areas of Tripura. Acta Horticulturae, 902: 291-298.

Directorate of Horticulture \& Soil Conservation (DHSC), 2019, Department of Agriculture, Govt. of Tripura.

Economic Review of Tripura 2017-18, Directorate of Economics \& Statistics Planning (DE\&SP) Department Government of Tripura, Agartala.

Hume, H.H. and Miller, H.K. 1904. Pineapple Culture II: varieties. Bull. Fla. Agric. Exp. Sta., 70: 37-62.

MART. 2011. Livelihood Based Agri. Business and Market Studies for North East Rural Livelihood Project: Final report, Tripura. MART, Noida - 201301, India.

National Horticulture Board. 2013. Indian Horticulture database. (www. nhb.gov.in)

National Horticulture Board. 2017. Area and Production of Horticulture Crops - All India 2015-16 to 2016-17 (Final). http://nhb.gov.in/statistics/State_Level/2016-17 (Final).pdf.

NSSO. 2014. Key indicators of situation of agricultural households in India. NSS 70 ${ }^{\text {th }}$ Round. Ministry of Statistics and Programme Implementation, Government of India

Priya Devi, S., Thangam, M., Ladaniya, M.S. and Singh, N.P. 2013: Pineapple-a profitable fruit for Goa. Technical Bulletin No. 35, ICAR (RC), Goa.

Py, C. Lacoeuilhe, J.J. and Teisson, C. 1987. The pineapple: cultivation and uses. G.P. Masonneuve and Larose. 15, Rue-Victor, Paris, pp. 568.
Rao, G.G., Shikhamany, S.D., Rao , J.V., Chadha, K.L. and Sharma, C.B. 1977. Performance of Kew pineapple (Ananas comosus L.) in three crop cycle grown under varying soil moisture regimes and nitrogen levels. Vatika, 1: 1-9.

Samson, J.A. 1984. Tropical fruits. Longman Group Ltd. Longman Inc. New York, pp. 250.

Sema, A., Maiti, C.S. and Dietholhou. 2011. Pineapple cultivation in north east India - a prospective venture. Acta Horticulturae, 902: 69-78.

Singh, N.P. 2005. Pineapple cultivation in Tripura, a technology bulletin for Tripura, ICAR Study.

Suchiradipta, B. and Saravanan, R. 2018. Status of Agricultural Market and Value Chain in Tripura. Working Paper 2, MANAGE Centre for Agricultural Extension Innovations, Reforms and Agripreneurship, National Institute for Agricultural Extension Management (MANAGE), Rajendranagar, Hyderabad, India.

The Assam Tribune, 2018. https://assamtribune.com/tripuraexports-pineapples-to-dubai?infinitescroll $=1$. (Accepted and Published on June 13, 2018)

The Times of India, 2018. https:/timesofindia.indiatimes.com/ indialpresident-declares-queen-pineapple-as-tripuras-statefruit/articleshow/64512923.cms. (Accepted and Published on June 8,2018 ). 